\title{
CANADIAN ANAESTHETISTS' SOCIETY MEDAL
}

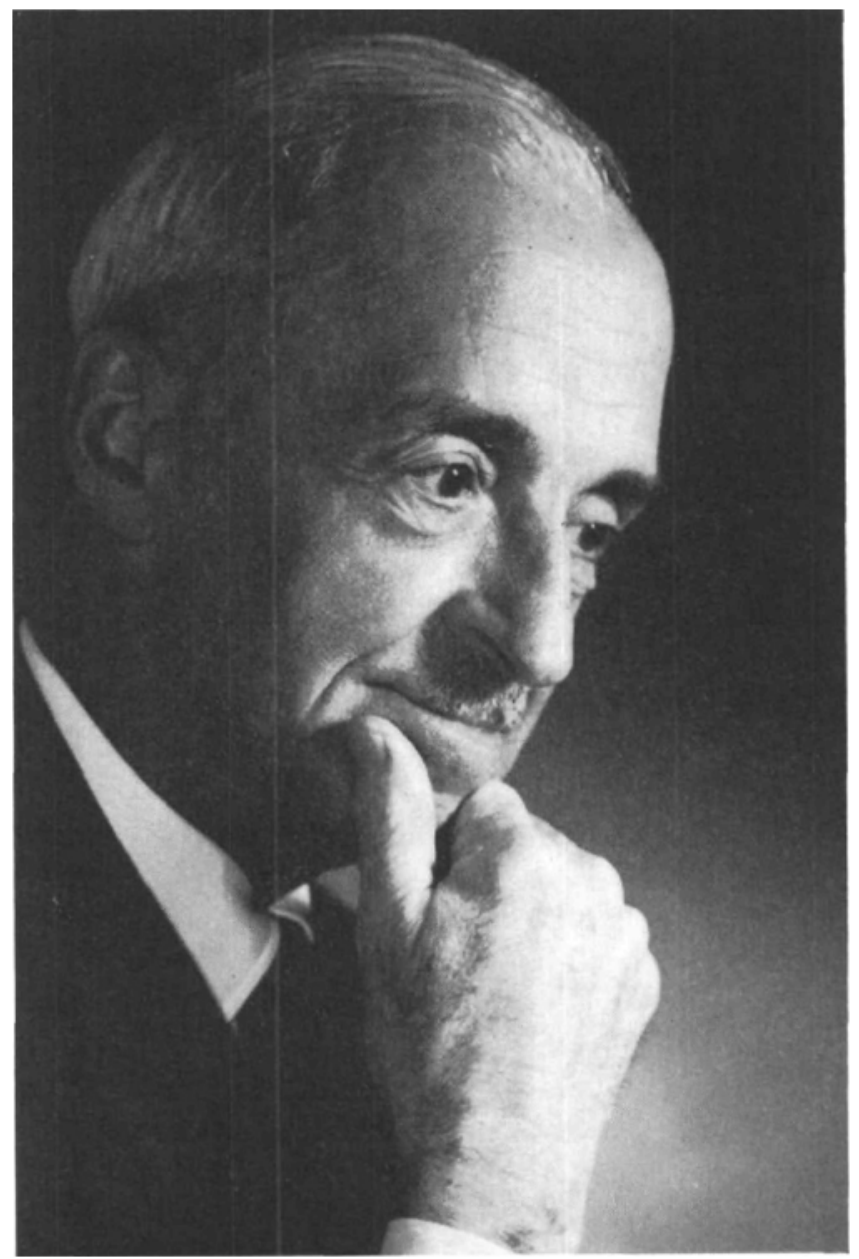

Georges CoUSineau, M.D., F.F.A.R.C.S.

Le docteur Georges Cousineau est né le 17 janvier 1906. Il était le sixième enfant de Monsieur et Madame Adélard Cousineau de Ville Saint-Laurent. C'est dans cette ville, alors beaucoup moins urbanisée qu'aujourd'hui, qu'il passa ses premières années.

Il reçut la première partie de son instruction au Collège Notre-Dame sur la rue Côte des Neiges puis au Collège Sainte-Thérèse à partir de 1919. C'est là qu'il se fit remarquer tant au point de vue scolaire que sportif. Il était le vice-président de sa classe. De plus il était le gardien de but du club officiel du Collège. L'histoire ne dit pas cependant quels furent les succès de son club. Ce goût 
pour les sports ne l'abandonna pas par la suite et le docteur Cousineau devint un aussi habile golfeur et skieur qu'il était bon nageur. Une intervention chirurgicale au dos vint cependant mettre fin à sa carrière sportive. Il dut alors changer la forme de ses loisirs pour des activités moins robustes. Les voyages devinrent alors son plus beau passe-temps.

En 1927, Georges termine au Collège Sainte-Thérèse et entre à la Faculté de l'Université de Montréal. En 1934, il obtient son Doctorat en Médecine avec la mention "grande distinction." Il se dirige alors vers la pratique générale à Cartierville et devient en même temps assistant anesthésiste dans le Service du regretté docteur Lachance à l'Hôpital Sacré-Cœur.

L’année suivante il épouse Marcelle, fille du regretté docteur Wilfrid Tétreault de Ville Saint-Laurent. Elle était alors étudiante à l'Ecole des Beaux Arts. Pour ne dire que quelques mots au sujet de Madame Cousineau, mentionnons qu'elle devint par la suite bien connue dans le milieu artistique et qu'elle se fit remarquer dans plusieurs expositions.

Le docteur Cousineau pratiqua dix ans à Cartierville, cependant l'anesthésie prenait progressivement la plus grande partie de son intérêt et de son temps. A la mort du docteur Lachance, le docteur Cousineau le remplaça à la tête du département. C'est là qu'il employa pour la première fois l'Evipan rapporté d'Europe par le docteur Norman Bethune. Durant les années qui suivirent, le docteur Cousineau dut faire un travail de pionnier en anesthésie pour la chirurgie thoracique.

En 1944, il se retire de la pratique générale et avec deux assistants consacre tout son temps à la pratique de sa spécialité. Après la conversion de l'Hôpital Sacré-Cœur en un grand hôpital général, le docteur Cousineau laisse ce poste pour s'occuper à la fois de l'administration et du département d'anesthésie de l'Hôpital Notre-Dame de l'Espérance. C'est ce poste qu'il occupe encore actuellement.

Le docteur Cousineau fut l'un des grands artisans de la formation de notre groupe tant au niveau provincial que national. Sa sagesse, sa fierté et son sens aigu de la justice, lui ont mérité une place dans de nombreux comités. Dans la province de Québec, les problèmes épineux n'étaient jamais abordés sans s'être d'abord posé la question: "Qu'est-ce que Georges suggèrerait?"

Sa signature accompagnait celle des docteurs Digby Leigh, Griffith, Rochette et Wesley Bourne au bas de la constitution et des règlements originaux de la Société Canadienne des Anesthésistes le 25 mai 1943 même avant son incorporation par lettres patentes le 21 juin 1943.

En 1953, le docteur Cousineau a été élu président de la Société Canadienne des Anesthésistes. Bien avant cette date et jusqu’à tout récemment, il représentait le Québec aux congrès nationaux.

Le docteur Cousineau était aussi un habitué des congrès provinciaux et il a participé à tous les comités importants.

En 1938, le docteur Cousineau reçoit un Fellowship de l'International Anaesthesia Research Association et en 1952, on lui décerne le titre d' "Honorary Fellow of the Faculty of Anaesthetists of the Royal College of Surgeons of England." 
Le docteur Cousineau a été pour quelque temps examinateur pour nos différents collèges. On dit qu'il a été le plus bienveillant de tous parce qu'il n'a jamais fait échouer personne.

En 1951, c'est lui qui a représenté la Société Canadienne des Anesthésistes en Angleterre et en France.

Le docteur Cousineau a aussi présidé plusieurs assemblées locales. Les réunions qui se sont déroulées chez lui, ont toujours été plus que de simples discussions, cela grâce à l'hospitalité de Madame Cousineau et des autres membres de sa famille.

Le docteur et madame Cousineau ont eu une fille, trois garçons et cinq petits enfants. Leur fille a suivi la tradition familiale et est devenue médecin elle aussi. Malheureusement, elle ne s'est pas spécialisée en anesthésie.

C'est donc sans crainte que nous pouvons affirmer que le docteur Cousineau est au plein sens du mot, un des "doyens" de notre spécialité.

Dr. Georges Cousineau was born January 17, 1906, the sixth child of Monsieur and Madame Adelard Cousineau of Ville Saint-Laurent. His childhood was spent in this country suburb of farms and open spaces.

He received his early education at the Collège Notre-Dame, Côte des Neiges, which he left in 1919 for the Collège Sainte-Thérèse. At the Collège SainteThérèse, he blossomed into both scholar and athlete. He is remembered as the vice-president of his class during his last two years, and was goal tender for the college hockey team. History does not relate the success or otherwise of this team. Georges' love of sports was continued subsequently when he became a very able skier, golfer, and swimmer. These activities were curtailed following an operation on his back and travel took the place of more vigorous hobbies.

In 1927, Georges left the Collège Sainte-Thérèse to enter the Medical School of the Université de Montréal. He graduated M.D. with "grande distinction" in 1934 and entered general practice at Cartierville, at the same time becoming assistant anaesthetist to the late Dr. Lachance at the Hôpital Sacré-Cœur.

The following year he married Marcelle, daughter of the late Dr. Wilfrid Tétreault of Ville Saint-Laurent. Marcelle had been up to that time a student of L'Ecole des Beaux Arts. Madame Cousineau has since become a well-known artist, showing at many exhibitions.

For ten years Dr. Cousineau practised in Cartierville, where he gradually became more interested in anaesthesia at the Sacré-Cœur. On the death of Dr. Lachance, Dr. Cousineau replaced him. It was here that Dr. Cousineau first used Evipan, brought back from Europe by the late Dr. Norman Bethune. During these years, Dr. Cousineau performed pioneer work in thoracic anaesthesia for Dr. Bethune and other thoracic surgeons.

In 1944, he retired from general practice to undertake the full-time practice of anaesthesia at the Sacré-Cœur, with two associates. With the expansion of the Hôpital Sacré-Cœur to become a large general hospital, Dr. Cousineau left to take over the Department of Anaesthesia and the administration of the Hôpital Notre-Dame de l'Espérance, which position he still holds. 
During the early years of the formation of groups of specialist anaesthetists in Canada, Dr. Cousineau was very active at both the national and provincial levels. His wisdom, level-headedness, and immaculate sense of justice has led to his appointment to many committees. The thorny problems in our professional field are never settled in Quebec without first asking "I wonder what Georges would advise?"

His signature was appended with those of Doctors Griffith, Rochette, Digby Leigh, and Wesley Bourne to the original by-laws of the Canadian Anaesthetists' Society, May 27, 1943, prior to its incorporation by letters patent, June 21, 1943.

From its formation in 1943 until 1965 Dr. Cousineau was a member of the Council of the Canadian Anaesthetists' Society. He was President of the Society 1953-54. Dr. Cousineau is always a regular attendant at provincial meetings and participates on all important committees.

Dr. Cousineau was granted a Fellowship in the International Anaesthesia Research Society in 1938, and in 1952 he was made an Honorary Fellow of the Faculty of Anaesthetists of the Royal College of Surgeons of England.

For a short while he was an examiner for the Royal College of Physicians and Surgeons of Canada and the Quebec College. Someone remarked that he was the kindest examiner ever known, for he never failed anyone.

In 1951, he represented the Canadian Anaesthetists' Society at meetings in Britain and later the same year in Paris.

Dr. Cousineau has chaired many local meetings. Those held at his home have been much more than simple discussions, for the participating members have been graciously entertained by Madame Cousineau and other members of their family.

Doctor and Madame Georges Cousineau have one daughter, three sons, and five grandchildren. Their daughter, Michelle, has followed in the family tradition in medicine. Unfortunately, she did not become an anaesthetist.

Doctor Georges Cousineau is in every sense one of the "deans" of our specialty. 